\title{
Screening Inherited Metabolic Disorders in Patients with Familial Mediterranean Fever
}

\section{Ailevi Akdeniz Ateși Ayııı Tanısında Doğumsal Metabolik Hastalıkların Değerlendirilmesi}

\author{
Ertuğrul Kıykım1, Ayşe Çiğdem Aktuğlu Zeybek1,Kenan Barut2,Tanyel Zubarioğlu1, Mehmet \\ Şerif Cansever3, Özgür Kasapçopur2 \\ 1 Istanbul University Cerrahpaşa Faculty of Medicine, Department of Pediatrics, Division of Nutrition and Metabolism, Istanbul, Turkey \\ 2 Istanbul University Cerrahpaşa Faculty of Medicine, Department of Pediatrics, Division of Rheumatology, Istanbul, Turkey \\ 3/stanbul University Cerrahpaşa Faculty of Medicine, Central Laboratory, Istanbul, Turkey
}

\begin{abstract}
Aim: Familial Mediterranean fever (FMF) is an autosomal recessive autoinflammatory disease, presenting with recurrent episodes of fever and polyserositis. Mitochondrial fatty acid oxidation disorders and porphyrias can present with periodic abdominal and muscle pain. The aim of this study was to determine the inherited metabolic disorders in differential diagnoses of Turkish pediatric FMF patients.

Materials and Methods: Hundred and seventy-four FMF patients were enrolled in the study. A fasting dry spot blood sample was taken for acylcarnitine analysis by tandem mass spectrometry from all patients. Fresh, light-protected spot urine test was performed for porphobilinogen screening. Second-tier test with urine organic acid analysis and urine porphyrin metabolites were performed if pathologic findings were detected in acylcarnitine profile or in porphobilinogen screening, for confirmation. Fifty healthy controls were included.

Results: Of the 174 patients diagnosed with FMF, none of them was diagnosed with porphyria; only one patient with multiple acyl-CoA dehydrogenase deficiency was detected during the study.

Conclusion: Our data revealed that screening for porphobilinogen for pediatric FMF patients is unnecessary, but an investigation of tandem mass spectrometry based acyl-carnitine analysis can be helpful in the differential or additional diagnosis of FMF in developing countries where there is no nationwide expanded newborn screening programme.

Keywords: Familial Mediterranean fever, inherited metabolic disorders, fatty acid oxidation disorders, porphyrias
\end{abstract}

ÖZ

Amaç: Ailevi Akdeniz ateşi (AAA) tekrarlayan serozit ve ateşle karakterize bir oto-inflamasyon sendromudur. Hastalık klinik bulguları ile genelde kolaylıkla tanınabilmekle birlikte özellikle çocuk yaş grubunda tanı koymakta zorluklar yaşanabilmektedir. Yağ asidi oksidasyon defektleri ve porfiryalar tekrarlayan kas ve karın ağrısına neden olabilmektedir. Türkiye'de yüksek akraba evliliği nedeniyle hem doğumsal metabolik hastalıklar hem de AAA sık görülmektedir. Çalışmamızda amacımız Türkiye'deki AAA hastalarııın ayrıcı tanısına girebilecek olan doğumsal metabolik hastalıkların saptanmasıdır

Gereç ve Yöntemler: AAA tanısıyla takip edilen 174 hasta çalışmaya alındı. Tüm hastalardan tandem M/S yöntemiyle asil-karnitin düzeylerinin çalışılması için parmaktan kuru kan örneği alındı. Tüm hastalardan taze idrar örneği ışıktan korunarak alındı ve idrarda porfobilinojen tayini yapıldı. Ilk testlerinde patolojik bulgu saptanan hastalardan ileri araştırma amaçıı idrar organik asit analizleri veya idrar porfirin metabolitleri çalışıldı. Çalısmamıza kontrol grubu olarak 50 sağlıkı çocuk alındı.

Bulgular: Çalışmaya alınmış 174 hastanın hiçbirisinde porfiri saptanmadı ancak multipl acil-CoA dehidrogenaz eksikliği olan bir hasta saptandı.

Sonuç: Çalışmamız sonucunda çocuk AAA hastalarında rutin porfiri araştırmasına gerek olmadığı ancak ülkemiz gibi genişletilmiş yenidoğan taramasının yapılmadığı ve akraba evliliği oranı yüksek olan ülkelerde tandem kütle spektrometrisi ile asil karnitin analizinin AAA hastalarında ayırıcı tanıda faydalı olabileceğini düşünmekteyiz.

Anahtar Kelimeler: Ailevi Akdeniz ateşi, doğumsal metabolik hastalıklar, yağ asidi oksidasyon defekti, porfiri 


\section{Introduction}

Familial Mediterranean fever (FMF) (OMIM: 249100) is an autosomal recessive disease characterized by recurring self-limited fever, abdominal pain and chest pain caused by serositis. Usually patients have additional joint and muscle pains. FMF is the most common hereditary periodic autoinflammation syndrome (1).

FMF mainly affects people of Middle-Eastern origin, including Turkish, Jewish, Armenian and Arab populations. In these ethnic groups, the prevalence of FMF is $1 / 200-1000$ with a high carrier rate of 1/3-5 (2-4).

The Mediterranean fever (MEFV) gene is located on chromosome 16, encodes a protein called 'pyrin'/'marenostin'. Pyrin plays a crucial role in the regulation of both inflammation and apoptosis $(5,6)$. Genetic testing for the MEFV gene has only $70-80 \%$ positive predictive value, thus the diagnosis of FMF is based on clinical presentation, family history and ethnic origin $(7,8)$

The diagnosis of FMF may be challenging in pediatric population. Differential diagnosis consists of other autoinflammatory syndromes (TNF-alpha associated periodic fever syndrome (TRAPS), Hyper IgD syndrome (HIDS), cyclic neutropenia, etc), surgical emergencies (pancreatitis, cholecystitis, etc), Lyme arthritis, inflammatory bowel disease, hereditary angioedema and porphyria (9-13).

Incidence of both FMF and IMD has increased in Turkish patients partially due to high consanguinity rates. FMF and IMD, especially fatty acid oxidation defects like multiple acyl co-A dehydrogenase deficiency, can present with similar symptoms that could result in diagnosing challenges. IMD must be a part of differential diagnosis in countries where expanded newborn screening (ENS) via tandem mass spectrometry is not a part of the nationwide newborn screening programme $(14,15)$.

Detection of MADD deficiency in a male patient, diagnosed with FMF and referred to the pediatric metabolic disease unit, after both his sisters died due to hypoglycemia and hepatocellular insufficiency, led us to investigate IMD in these patients. Both sisters were also followed up after being diagnosed with FMF.

The aim of the present study is to determine the IMDs in differential diagnosis of Turkish pediatric FMF patients.

\section{Materials and Methods}

\section{Study Design and Population}

174 patients who were diagnosed with FMF were enrolled in the present study. All diagnoses were confirmed by a child rheumatologist according to Yalçınkaya et al. criteria (16). Patients' clinical data, including detailed family history (consanguinity, additional affected individuals, ethnicity, etc.), age, gender, diagnosed age, additional clinical symptoms (fatigue, muscle pains-cramps, psychological symptoms, and dermatitis), medications, drug responses and laboratory data including complete blood count, glucose, transaminases, urea, creatinine, CPK, lipid profile, C-reactive protein (CRP), erythrocyte sedimentation ratio (ESR) and FMF mutation analyses of FMF were all documented. All patients underwent a careful physical examination. Age and sex matched 50 healthy subjects served as the control group. Patients with an additional diagnosis (inflammatory bowel disease, etc.) and those under carnitine treatment were excluded from the study.

Fasting dried spot blood samples consisted of capillary blood collected on Whatmann S\&S 903 filter paper were taken for free carnitine and acyl-carnitine analysis from children in both groups. The sampling was done by finger prick. The samples were dried in room temperature.

Relevant AC butryl esters were extracted and derivatized from $1 / 3$ inch dried blood samples and were analyzed using a protocol described by Schulze et al. previously (17). AC butryl esters were detected due to mass/ion ratios via quadripole electrospray tandem mass spectrometry (ESI-MS/ MS). Agilent 1200 series auto sampler and Water Micromass Quattro LC Likrom ${ }^{\mathrm{TM}}$ tandem mass spectrometry were used for the analyses. AC profile was screened by positive ion mod m/z 85 parents (?) screening function. The quantitative values of signal intensities were calculated using Masslynx and Neolynxsoftwares (Ver 4.1). Both signal intensities and calculated concentrations were exported to spreadsheet software where flagging abnormal concentrations and further evaluations were done $(17,18)$.

Fresh, light-protected spot urine test, described by Watson-Schwartz, was performed for porphobilinogen screening (Watson-Schwartz test; colorless pyrolle porphobilinogen forms a red-violent pigment after reaction with p-dimethylaminobenzaldehyde).

Second-tier test with urine organic acid analysis and urine porphyrin metabolites were performed for confirmation if pathologic findings were detected in acyl-carnitine profile or in porphobilinogen screening.

The study was reviewed and approved by the Ethics Committee of Cerrahpaşa Medical Faculty, Istanbul University. Signed informed consent was obtained from all patients who participated in the study. The investigation conforms to the principles outlined in the Declaration of Helsinki.

\section{Results}

174 patients diagnosed with FMF were enrolled in the study. Patients' clinical and demographic characteristics are shown in Table I.

Spot urine test for porphobilinogen was found positive in 4/174 of FMF patients, while none of these patients had abnormal porphyrin metabolites in their 24 hour-urine samples. None of the children in the control group turned out positive in spot porphobilinogen urine test.

Acyl-carnitine analysis in spot dried blood test using tandem mass spectrometry was performed to all patients. One patient with multiple acyl-CoA dehydrogenase deficiency (MADD) was detected during the study. None of the children in the control group showed pathologic acylcarnitine profile. 


\section{Case Report}

The patient is a 13-year-old boy with complaints of recurrent abdominal pain, muscle pain and vomiting. His parents were consanguineous (first degree cousins) and had several relatives diagnosed with FMF. He was also diagnosed with FMF and colchicine treatment was started. He didn't use colchicine regularly because his complaints sustained under this treatment. He had several attacks presenting with vomiting, abdominal and muscle pain responding to IV dextrose infusion. His physical examination was normal; he had no mental retardation, no hepatomegaly and no abnormal neurological findings.

His first line investigations revealed a positive urine porphobilinogen test, but urine porphyrin profile was normal. His acyl-carnitine profile revealed high levels of C5-, C8-, C10-, C12-, C5DC-, C14:2-, C14:1- and C14 acyl-carnitine levels $(0.620 \mu \mathrm{M} / \mathrm{L}, 1.5 \mu \mathrm{M} / \mathrm{L}, 3.5 \mu \mathrm{M} / \mathrm{L}, 2.55 \mu \mathrm{M} / \mathrm{L}, 1.03$ $\mu \mathrm{M} / \mathrm{L}, 0.210 \mu \mathrm{M} / \mathrm{L}, 0.960 \mu \mathrm{M} / \mathrm{L}, 1,47 \mu \mathrm{M} / \mathrm{L}$ respectively). 3-OH-butyric acid, 3-OH-sebacic acid, adipic acid, acetoacetic acid, suberic acid, glutaric acid and 3-OH-isovaleric acid excretion was detected in organic acid analyses. MADD was considered in diagnosis. Riboflavin and coenzyme Q10 therapies along with a frequent feeding to avoid fasting were initiated. Excellent response to treatment was achieved, acyl-carnitine levels were normalized and his clinical complaints were resolved. A homozygous mutation on ETFDH gene (c.1330T>C(p.L377P) was detected, confirming MADD diagnosis.

\section{Discussion}

In the present study we screened FMF patients for differential diagnoses of FAODs andporphyrias.

Porphyrias are a group of inherited metabolic disorders of haem biosynthesis $(14,19)$. Clinically they can be differentiated into acute and non-acute porphyrias. Specific patterns of acute accumulation of the haem precursors are associated with clinical features; abdominal, psychiatric and neurological symptoms $(20,21)$. The clinical manifestations

Table I. Demographic and clinical characteristics of familial Mediterranean fever patients and control subjects

\begin{tabular}{|l|l|l|}
\hline Variables & FMF patients & Control group \\
\hline Sex (Male/Female) & $92 / 82$ & $27 / 23$ \\
\hline Age (Months) & $131.28 \pm 52.05$ & $132.11 \pm 52.3$ \\
\hline Initial complain starting age (Months) & $59.89 \pm 36.64$ & \\
\hline Diagnosing age (Months) & $88.92 \pm 44.12$ & \\
\hline Clinical characteristics & & \\
\hline Abdominal pain and fever & $168 / 174(96.5 \%)$ & \\
\hline Musculoskeletal findings & $98 / 174(56.3 \%)$ & \\
\hline Fatigue & $80 / 174(45.9 \%)$ & \\
\hline Skin lesions & $12 / 174(8 \%)$ & \\
\hline
\end{tabular}

FMF: Familial Mediterranean fever of acute porphyrias are extremely rare before puberty and generally give the first clues in early 30's, maybe with pregnancy (21). Most patients have one or a few attacks and then recover fully for the rest of their lives and less than $10 \%$ develop recurrent attacks. Physical examination shows no abnormalities and laboratory investigations are usually remarkable.Porphyrias are often misdiagnosed because of their multiform clinical manifestations, able to mimic other diseases, including FMF. Clinical features alone are not sufficient to confirm the diagnosis; specific laboratory investigations are mandatory for the accurate diagnosis and management of the disease $(22,23)$.

Erhlich's reagent-based tests are simple and rapid assays to test the presence of urinary porphobilinogen. Examination of urine for excess porphobilinogen is the first line test for the suspected acute porphyria attack. During remission, urine, blood or fecalporphorin concentrations are generally normal in acute porphyrias, making it more difficult to diagnose accurately when the patient is between acute crises $(21,24$ 26). Although screening for urine porphobilinogen revealed 4 patients with a positive screening test, investigation of urine for porphyrin metabolites rendered normal results and no patient was diagnosed with porphyria. One of the limitations that could have influenced our study was that the urine samples were not taken during an acute attack (acute abdomen or muscle weakness). Previous studies have revealed that porphyrin metabolites would usually be within normal limits between acute crises. Also the initial symptom age was not appropriate for the initial acute porphyria attack, and the numbers of male and female patients were equal in the study group while female dominance is expected for porphyria.

Fatty acid oxidation plays a major role in energy production especially in catabolic stages. FAODs are a group of disorders of energy metabolism with a high prevalence in Europe. The toxic effects of accumulated acyl-carnitines and acyl-CoA species and energy deficiency due to impaired fatty acid and ketone body formation are responsible for the clinical manifestations (27). The clinical findings and symptoms are very heterogeneous. The classical presentation in the newborn is acute hypoketotic hypoglycemia, encephalopathy and liver dysfunction. Severe cardiomyopathy, arrhythmias or conduction defects are some of the other leading symptoms. Older children and adults may present with exercise-illness induced myopathy, muscle weakness, with pain or with acute rhabdomyolysis or cyclic vomiting (28). Each FAODs have a specific acyl-carnitine profile but a genotypic correlation is warranted for accurate diagnosis.

In the present study, we investigated FAODs in Turkish FMF patients and we found one patient with MADD. MADD results from defects of electron transfer flavoprotein (ETF) or ETF ubiquinone oxidoreductase (ETFQO). ETY and ETFQO carry electrons to the respiratory chain from multiple dehydrogenases linked to flavin adenine dinucleotide (FAD). The clinical picture is diverse ranging from a fatal disease in the newborn with hypoglycemia, hyperammonemia and 
acidosis accompanied by hepatomegaly to muscle weakness, recurrent bouts of vomiting in later childhood or adulthood. The riboflavin responsive phenotype has a good prognosis (29). Our patient is a 13-year-old boy with complaints of cyclic attacks of abdominal pain, muscle pain and vomiting. The diagnosis of MADD was confirmed by mutation analysis, and treatment with riboflavin and a high calorie diet with frequent feeding to avoid fasting resulted in an excellent response. Overall positive family history, positive mutation on MEFV gene and symptoms resembling acute FMF attack can easily lead FAODs to be misdiagnosed.

Countries like Turkey with high consanguinity rates have an increased incidence risk of inherited disorders like FMF or IMDs. In the present study parental consanguinity was found in $29.9 \%$ of the patients while the reported consanguinity rate in Turkey was $23.3 \%$ (30). As the consanguinity ratio in Turkish FMF patients was higher than the normal population, our study group consisted of patients with a high risk for inborn errors of metabolism that are usually autosomal recessively inherited. FAODs can be easily diagnosed in the newborn in countries where ENS with tandem mass spectrometry is a part of the nationwide screening. Unfortunately ENS with MS/MS is not a part of the nationwide newborn screening programme and the prevalence of FAODs is still unknown.

The present study is the first to investigate IMDs in the differential diagnosis of FMF. Our data revealed that screening for porphobilinogen for pediatric FMF patients is unnecessary, but an investigation of tandem mass based acyl-carnitine analysis can be helpful for the differential or additional diagnosis of FMF in developing countries where there is no nationwide ENS.

\section{Authorship Contributions}

Ethics Committee Approval: The study was reviewed and approved by the Ethics Committee of Cerrahpaşa Medical Faculty, Istanbul University, Informed Consent: Signed informed consent was obtained from all patients who participated in the study, Concept: Ertuğrul Kıykım, Mehmet Şerif Cansever, Kenan Barut, Design: Ertuğrul Kıykım, Tanyel Zubarioğlu, Ayşe Çiğdem Aktuğlu Zeybek, Özgür Kasapcopur, Data Collection or Processing: Ertuğrul Kıykım, Mehmet Şerif Cansever, Ayse Çiğdem Aktuğlu Zeybek, Kenan Barut, Analysis or Interpretation: Ertuğrul Kıykım, Mehmet Şerif Cansever, Ayşe Çiğdem Aktuğlu Zeybek, Literature Search: Ertuğrul Kıykım, Ayse Çiğdem Aktuğlu Zeybek, Tanyel Zubarioğlu, Writing: Ertuğrul Kıykım, Tanyel Zubarioğlu, Kenan Barut, Özgür Kasapcopur, Peerrewiev: Externally peer-reviewed, Conflict of Interest: No conflict of interest was declared by the authors, Financial Disclosure: The authors declared that this study has received no financial support.

\section{References}

1. Ozen S, Bilginer Y. A clinical guide to autoinflammatory diseases: familial Mediterranean fever and next-of-kin. Nat Rev Rheumatol 2014; 10: 135-47.
2. Daniels M, Shohat T, Brenner-Ullman A, Shohat M. Familial Mediterranean fever: high gene frequency among the nonAshkenazic and Ashkenazic Jewish populations in Israel. Am J Med Genet 1995; 55: 311-4.

3. Yilmaz E, Ozen S, Balci B, et al. Mutation frequency of Familial Mediterranean Fever and evidence for a high carrier rate in the Turkish population. Eur J Hum Genet 2001; 9: 553-5.

4. Rogers DB, Shohat M, Petersen GM, et al. Familial Mediterranean fever in Armenians: autosomal recessive inheritance with high gene frequency. Am J Med Genet 1989; 34: 168-72.

5. Pras E, Aksentijevich I, Gruberg L, et al. Mapping of a gene causing familial Mediterranean fever to the short arm of chromosome 16. N Engl J Med 1992; 326: 1509-13.

6. French FMF Consortium. A candidate gene for familial Mediterranean fever. Nat Genet 1997; 17: 25-31.

7. Soriano A, Manna R. Familial Mediterranean fever: new phenotypes. Autoimmun Rev 2012; 12: 31-7.

8. Berkun $Y$, Eisenstein EM. Diagnostic criteria of familial Mediterranean fever. Autoimmun Rev 2014; 13: 388-90.

9. Portincasa P, Scaccianoce G, Palasciano G. Familial mediterranean fever: a fascinating model of inherited autoinflammatory disorder. Eur J Clin Invest 2013; 43: 131427.

10. Dale DC, Welte K. Cyclic and chronic neutropenia. Cancer Treat Res 2011; 157: 97-108.

11. Gattorno M, Caorsi R, Meini A, et al. Differentiating PFAPA syndrome from monogenic periodic fevers. Pediatrics 2009; 124: 721-8.

12. Posch C, Kaulfersch W, Rappersberger K. Cryopyrinassociated periodic syndrome. Pediatr Dermatol 2014; 31: 228-31.

13. Sinha A, Waterham HR, Sreedhar KV, Jain V. Novel mutations causing hyperimmunoglobulin $D$ and periodic fever syndrome. Indian Pediatr 2012; 49: 583-5.

14. Puy H, Gouya L, Deybach JC. Porphyrias. Lancet 2010; 375: 924-37.

15. Morris AA, Spiekerkoetter U. Disorders of mitochondrial fatty acid oxidation and related metabolic pathways. In: Saudubray JM, van den Berghe G, Walter JH (eds). Inborn metabolic diseases diagnosis and treatment, 5th. Springer, New York, 2012; 201-2017.

16. Yalçinkaya F, Ozen S, Ozçakar ZB, et al. A new set of criteria for the diagnosis of familial Mediterranean fever in childhood. Rheumatology (Oxford) 2009; 48: 395-8.

17. Schulze A, Lindner M, Kohlmüller D, Olgemöller K, Mayatepek E, Hoffmann GF. Expanded newborn screening for inborn errors of metabolism by electrospray ionization-tandem mass spectrometry:results, outcome, and implications. Pediatrics 2003; 111: 1399-406.

18. Millington DS, Norwood DL, Kodo N, Roe CR, Inooe F. Application of fast atom bombardment with tandem mass spectrometry and liquid chromatography/mass spectrometry to the analysis of acylcarnitines in human urine, blood and tissue. Anal Biochem 1989; 180: 331-9.

19. Elder $\mathrm{GH}$, Hift RJ, Meissner PN. The acute porphyrias. Lancet 1997; 349: 1613-7.

20. Kauppinen R. Porphyrias. Lancet 2005; 365: 241-52.

21. Ventura $P$, Cappellini MD, Rocchi E. The acute porphyrias: a diagnostic and therapeutic challenge in internal and emergency medicine. Intern Emerg Med 2009; 4: 297-308. 
22. Anderson KE, Sassa S, Bishop DF, Desnick RJ. Disorders of heme biosynthesis: X-linked sideroblastic anemia and the porphyrias. In: Scriver CR, Beaudet A, Sly WS, Valle D (eds). The metabolic and molecular basis of inherited diseases. McGraw-Hill, New York, 2001; 2991-3062.

23. Hultdin J, Schmauch A, Wikberg A, Dahlquist G, Andersson C. Acute intermittent porphyria in childhood: a populationbased study. Acta Paediatr 2003; 92: 562-8.

24. Kauppinen R, von und zu Fraunberg M. Molecular and biochemical studies of acute intermittent porphyria in 196 patients and their families. Clin Chem 2002; 48: 1891-900.

25. Lim CK, Peters TJ. Urine and faecal porphyrin profiles by reversed phase high-performance liquid chromatography in the porphyrias. Clin Chim Acta 1984; 139: 55-63.

26. Aarsand AK, Petersen PH, Sandberg S. Estimation and application of biological variation of urinary delta- aminolevulinic acid and porphobilinogen in healthy individuals and in patients with acute intermittent porphyria. Clin Chem 2006; 52: 650-6.

27. Spiekerkoetter $U$, Duran M. Mitochondrial fatty acid oxidation disorders. In: Blau N, Duran M, Gibson KM, Dionisi-Vici C (eds). Physician's guide to the diagnosis, treatment, and follow-up of inherited metabolic diseases. 2th ed. Springer, New York, 2014; 247-64.

28. Roe CR, Ding J. Mitochondrial fatty acid disorders, in Scriver CR, Beaudet AL, Sly WS (eds). The metabolic molecular bases of inherited disease. New York, NY, McGraw-Hill, 2001; 2297-326.

29. Olsen RK, Olpin SE, Andresen BS, et al. ETFDH mutations as a major cause of riboflavin-responsive multiple acyl-CoA dehydrogenation deficiency. Brain 2007; 130: 2045-54.

30. Turkish statistical institute. www.turkstat.gov.tr/ PreHaberBultenleri.do?id=13458. Accessed 08 March 2013. 